\title{
A Discussion of Los cachorros (1967) by Mario Vargas Llosa as a Nouvelle or Short Novel: Its Discourse and the Theme of Identity
}

\author{
José Cardona-López ${ }^{1}$
}

The modern short novel or nouvelle is a specific and autonomous literary form which, at least from the beginning of the $19^{\text {th }}$ century until the last third of the $20^{\text {th }}$ century, has concerned some writers and critics from Europe, the United States and the Hispanic world. After present and discuss some academic and theoretical approaches on the modern short novel or nouvelle, I will analyze Los cachorros (1967) by Mario Vargas Llosa, identifying in it some features of that literary form. The main emphasis of my article will fall on the analysis of the theme of identity that embodies the life of Cuéllar, the protagonist. I will also discuss the form and means the author uses to develop a careful and particular style in the narrative discourse. [Article copies available for a fee from The Transformative Studies Institute. E-mail address: journal@transformativestudies.org Website: http://www.transformativestudies.org (C2019 by The Transformative Studies Institute. All rights reserved.]

KEYWORDS: Nouvelle, Novellentheorie, Discourse, Orality, Identity.

\section{SOME CONSIDERATIONS ABOUT THE SHORT NOVEL OR NOUVELLE}

Traditionally the study of this literary form has been overlooked in Spanish American literary criticism and academia. However, in the last

\footnotetext{
${ }^{1}$ José Cardona-López, Ph.D., is Full Professor (Regents Professor) of Hispanic American Literature and Creative Writing at Texas A\&M International University. His research interest is focused on Spanish American narrative (especially on short novel or nouvelle) and poetry. He is a Contributing Editor to the Handbook of Latin American Studies (Library of Congress). His book entitled Teoría y práctica de la nouvelle (2003) is devoted to present and discuss the most important theoretical approaches to the study of modern nouvelle or short novel. As fiction writer he has published the short novel Mercedes (e-book, 2014), the novel Sueños para una siesta (1986), and several short stories collections: La puerta del espejo (1983), Siete y tres nueve (2003), Todo es adrede (1991, 2009), and Al otro lado del acaso (2012). Address correspondence to: José Cardona; e-mail: cardona@tamiu.edu.
}

1937-0229 (2019 Transformative Studies Institute 